\title{
SOCIO-PSYCHOLOGICAL BARRIERS TO RESOLVE PEACEFULLY INTRACTABLE CONFLICTS
}

\author{
Daniel Bar-Tal ${ }^{1}$ \\ Tel-Aviv University, Israel
}

\begin{abstract}
Intensive and violent intergroup conflicts that rage in different parts of the world are real. These conflicts centre over disagreements focusing on contradictory goals and interests in different domains and must be addressed in conflict resolution. It is well known that the disagreements could potentially be resolved, if there were no powerful socio-psychological barriers which fuel and maintain the conflicts. These barriers inhibit and impede progress towards peaceful settlement of the conflict. They stand as major obstacles to begin the negotiation, to continue the negotiation, to achieve an agreement and later to engage in a process of reconciliation. These barriers are found among both leaders and society members that are involved in vicious, violent and protracted intergroup conflicts. They pertain to the integrated operation of cognitive, emotional and motivational processes, combined with a pre-existing repertoire of rigid supporting beliefs, worldviews and emotions that result in selective, biased and distorted information processing. This processing obstructs and inhibits the penetration of new information that can potentially contribute to facilitating the progress in the peace-making process.
\end{abstract}

Keywords: Psychological barriers, ethos of conflict, intergroup emotions, Israeli-Palestinian conflict

\footnotetext{
${ }^{1}$ daniel@tauex.tau.ac.il
} 


\section{Introduction}

Intergroup conflicts are an inherent part of human relations and they take place continuously and constantly on a large scale through millenniums. However, of special interest are intergroup conflicts called intractable that have very distinguished characteristics and are also an inseparable part of intergroup relations. They are over contradictory goals that are viewed as being existential, are violent, perceived by the involved parties as being of zero sum nature and irresolvable, deeply involve the engaged societies which invest much resources in their continuation and, last at least, a generation (Bar-Tal, 1998, 2007, 2013; Kriesberg, 1993, 2007). These vicious conflicts still rage in various parts of the globe as for example in Sri Lanka, Kashmir, Chechnya, Northern Ireland, or the Middle East. They centre over disagreements on contradictory goals and interests in different domains such as territories, natural resources, economic wealth, self-determination, and/or basic values and these real disagreements have to be addressed in conflict resolution. Potentially, the disagreements could be resolved with different processes such as negotiation, mediation or arbitrations, but the reality demonstrates that conflicts over goals perceived as being existential are rarely resolved within a short time. They last often through decades and even centuries with much violence that causes immense suffering of the societies involved. I suggest that one major reason for their continuation is operation of various powerful barriers that fuel and maintain the conflicts.

These barriers, which underlie the mere disagreements, are powerful forces that inhibit and impede progress towards peaceful settlement of the conflict. They stand as major obstacles to begin the negotiation, to continue the negotiation, to achieve an agreement and later to engage in a process of reconciliation. I specifically focus on the socio-psychological barriers that are of special importance, as they have dominant detrimental power in preventing peace-making (Arrow, Mnookin, Ross, Tversky, \& Wilson, 1995; Bar-Tal \& Halperin, 2011: Ross \& Ward, 1995). They function on the level of leaders and society members, as well.

The paper will first present evolvement of culture of conflict that provides the foundation for the emergence of the socio-psychological barriers. Then, it will describe the barriers functioning on societal level. The next part will introduce a general integrative model of socio-psychological barriers on the individual level. A conceptual framework will later be presented, proposing ways to overcome the socio-psychological barriers. Finally, several conclusions will be presented. 


\section{Development of the Socio-psychological Barriers}

The point of departure is that intractable conflicts have an imprinting effect on the individual and collective life in the participating societies. The above described characteristics of intractable conflict imply that society members living under these harsh conditions experience severe and continuous negative psychological effects, such as chronic threat, stress, pain, uncertainty, exhaustion, suffering, grief, trauma, misery, and hardship, both in human and material terms (see for example, Cairns, 1996; de Jong, 2002; Milgram, 1986; Robben \& Suarez, 2000). Also, an intractable conflict requires constant mobilization of society members to support and actively take part in it, even to the extent of willingness to sacrifice their lives. In view of these experiences, society members need to adapt to the harsh conditions by satisfying their basic human needs, learning to cope with the stress, and developing psychological conditions that will be conducive to successfully withstanding the rival group.

A basic premise is that in order to meet the above challenges, societies in intractable conflict develop set of functional beliefs, attitudes, emotions, values, motivations, norms, and practices (Bar-Tal, 2007, 2013). They provide meaningful picture of the conflict situation, justify the behaviour of the society, facilitate mobilization for participation in the conflict, enable maintenance of positive social identity and self-collective image. These elements of the socio-psychological repertoire on the individual and collective levels gradually crystallize into a well-organized system of societal shared beliefs ${ }^{2}$, attitudes and emotions that penetrates into institutions and communication channels of the society and become part of the socio-psychological infrastructure. This socio-psychological infrastructure includes collective memories ${ }^{3}$, ethos of conflicts $^{4}$ and collective

${ }^{2}$ Societal beliefs are the building block of narratives. They are defined as shared cognitions by the society members that address themes and issues that the society members are particularly occupied with, and which contribute to their sense of uniqueness (Bar-Tal, 2000).

${ }^{3}$ Collective memory of conflict describes the outbreak of the conflict and its course, providing a coherent and meaningful picture of what has happened from the societal perspective (Bar-Tal, 2007, 2013; Devine-Wright, 2003; Papadakis, Perstianis, \& Welz, 2006; Tint, 2010).

${ }^{4}$ Ethos of conflict is defined as the configuration of shared central societal beliefs that provide a particular dominant orientation to a society at present and for the future (Bar-Tal, 2000, 2007, 2013). It is composed of eight major themes about issues related to the conflict, the in-group, and its adversary: (1) societal beliefs about the justness of one's own goals, which outline the contested goals, indicate their crucial importance, and provide their explanations and rationales; (2) Societal beliefs about security stress the importance of personal safety and national survival, and outline the conditions for their achievement; (3) Societal beliefs of positive collective self-image concern the ethnocentric tendency to attribute positive traits, values, and behavior to one's own society; (4) Societal beliefs of victimization concern the self-presentation of the in-group as the victim of the conflict; (5) Societal beliefs of delegitimizing the opponent concern beliefs that deny the adversary's humanity; (6) Societal beliefs of patriotism generate attachment to the country and society, by propagating loyalty, 
emotional orientation ${ }^{5}$ that are in mutual interrelations-they provide the major narratives, motivators, orientations, and goals that society members need in order to carry their life under the harsh conditions of intractable conflict and support its continuation. Eventually this infrastructure becomes well institutionalized and disseminated and serves as a foundation to the development of culture of conflict that dominates societies engaged in intractable conflicts (Bar-Tal, 2010, 2013).

This introduction aims to present the basis whereon the sociopsychological barriers that serve as powerful forces in societies involved in intractable conflicts evolve. These barriers are grounded in the culture of conflict in which the narratives of ethos of conflict and collective memory are its pillars. The narratives provide a very simplistic and one-sided picture that serves as a prism for viewing conflict reality. In addition, these narratives are grounded in shared emotions that add another powerful vector to the functioning of the barriers. All these factors play a major role in preventing information processing that opens new perspectives that may facilitate peace-making process. We can now elaborate more on the socio-psychological barriers.

The discussion of the socio-psychological barriers is divided into two parts. The first part, concerns the societal mechanisms that actively play a role in setting barriers for preventing the flow of alternative information that contradicts the narratives of ethos of conflict and collective memory and indicate a way for a possibility to resolve the conflict peacefully. The second part describes the nature and functioning of the barriers on the individual level by society members who are involved in intractable conflicts and support it. The main argument advanced in this paper is that although socio-psychological barriers function on individual level, this functioning is greatly affected by the dominant political culture of conflict that provides opportunities and restrictions to the flow of information about the conflict. They provide the social environment in which individual society members collect information, form experiences and then process them. Societies involved in intractable conflict very often actively make efforts to maintain the conflict supporting narrative and prevent penetration of the alternative beliefs that may undermine this dominance. They use various societal mechanisms to block the appearance and dissemination of information

\footnotetext{
love, care, and sacrifice; (7) Societal beliefs of unity refer to the importance of ignoring internal conflicts and disagreements during intractable conflicts to unite the society's forces in the face of an external threat; Finally, (8) Societal beliefs of peace refer to peace as the ultimate desire of the society. ${ }^{5}$ Collective emotional orientation refers to societal characterization of an emotion that is reflected on individual and collective level in socio-psychological repertoire, as well as in tangible and intangible societal symbols such as cultural products or ceremonies (Bar-Tal, 2001, 2013).
} 
that provides an alternative view about the conflict, about the rival, about one's own group and/or about the conflict goals.

These mechanisms can be viewed as societal barriers and will now be described.

\section{Societal Mechanisms as Barriers}

The use of societal mechanisms comes to block alternative information and narratives from entering social spheres and tries that even when they penetrate they will be rejected -so society members would not be persuaded by their evidence and arguments (Bar-Tal, 2007; Bar-Tal, Oren, \& Nets-Zehngut, 2014; Horowitz, 2000; Kelman, 2007). The use of societal mechanisms can be activated by the formal authorities of the in-group- in some cases of the state-- or by other agents of conflict, who have vested interest in preventing dissemination of alternative information. The following mechanisms are noted:

\section{Control of information}

This mechanism refers to selective dissemination of information about the conflict within the society by formal and informal societal institutions (e.g., state ministries, the army and the media) that provide information that sustains the dominant conflict-supportive narrative, while suppressing information that may challenge it (e.g., Dixon, 2010).

\section{Discrediting of counter information}

This category encompasses methods that attempt to portray information that supports counter narratives and/or its sources (individuals or entities) as unreliable and as damaging to the interests of the in-group (Berger, 2005).

\section{Monitoring}

This mechanism, which is conducted by formal and informal societal institutions, refers to the regular scrutiny of information that is being disseminated to the public sphere (e.g. school textbooks, NGO reports, mass media news, studies of scholars, and so on) in order to identify information that contradicts the conflict-supportive narratives, expose the sources of such information and sanction them so that they stop disseminating such information (Avni \& Klustein, 2009). 


\section{Punishment}

When individuals and entities challenge the hegemony of the dominant narrative, they may face sanctions. These sanctions can be formal and informal, of social, financial and physical nature, and are aimed at discouraging these challengers from conducting their activities and thereby in effect silencing them (Carruthers, 2000).

\section{Restricting use of archives}

This mechanism aims to prevent the public exposure of documents stored in archives (especially state archives) that may contradict the dominant narrative (Brown \& Davis-Brown, 1998).

\section{Censorship}

This mechanism refers to the prohibition on publication of information in various products (e.g., newspapers articles, cultural channels and official publications) that challenge the themes of the dominant conflict-supportive narratives (Peleg, 1993).

\section{Encouragement and rewarding mechanism}

Encouragement and rewarding mechanism uses a "carrot" for those sources, channels, agents and products that support the psychological repertoire of conflict.

We can turn now to the discussion of the functioning of the sociopsychological barriers on the individual level.

\section{Socio-psychological Barriers on the Individual Level: Freezing}

The discussion of the socio-psychological barriers on the individual level must begin with the knowledge that in all the societies involved in intractable conflicts, in their climax, at least a significant portion of the society members hold in their repertoire narratives of ethos of conflict and of collective memory and some hold them even as central and with high confidence. These conflictsupporting narratives are the pillars of culture of conflict, providing particular illumination of conflict that is widely used in the society. Theoretically, the conflict supporting narratives could be easily changed with persuasive arguments that provide information about costs of the conflict, humane characteristics of the rival, rivals willingness to negotiate peaceful resolution, immoral acts of the 
in-group and so on. However, in reality this change rarely happens in short time ${ }^{6}-$ even when society members are presented with alternative valid information that refutes their beliefs, they continue to adhere to them. One of the reasons for this functioning are socio-psychological barriers that are defined as "an integrated operation of cognitive, emotional and motivational processes, combined with preexisting repertoire of rigid conflict supporting beliefs, world views and emotions that result in selective, biased and distorting information processing" (Bar-Tal \& Halperin, 2011, p. 220). Thus, the individual functioning of the barriers results in one-sided information processing that obstructs and inhibits a penetration of new information that can contribute to the facilitation of the development of the peace process. That is, individuals are not interested even in exposure to alternative information that may contradict their held societal beliefs about the conflict (see Figure 1).

Figure 1: Socio-Psychological Barriers to Peaceful Conflict Resolution

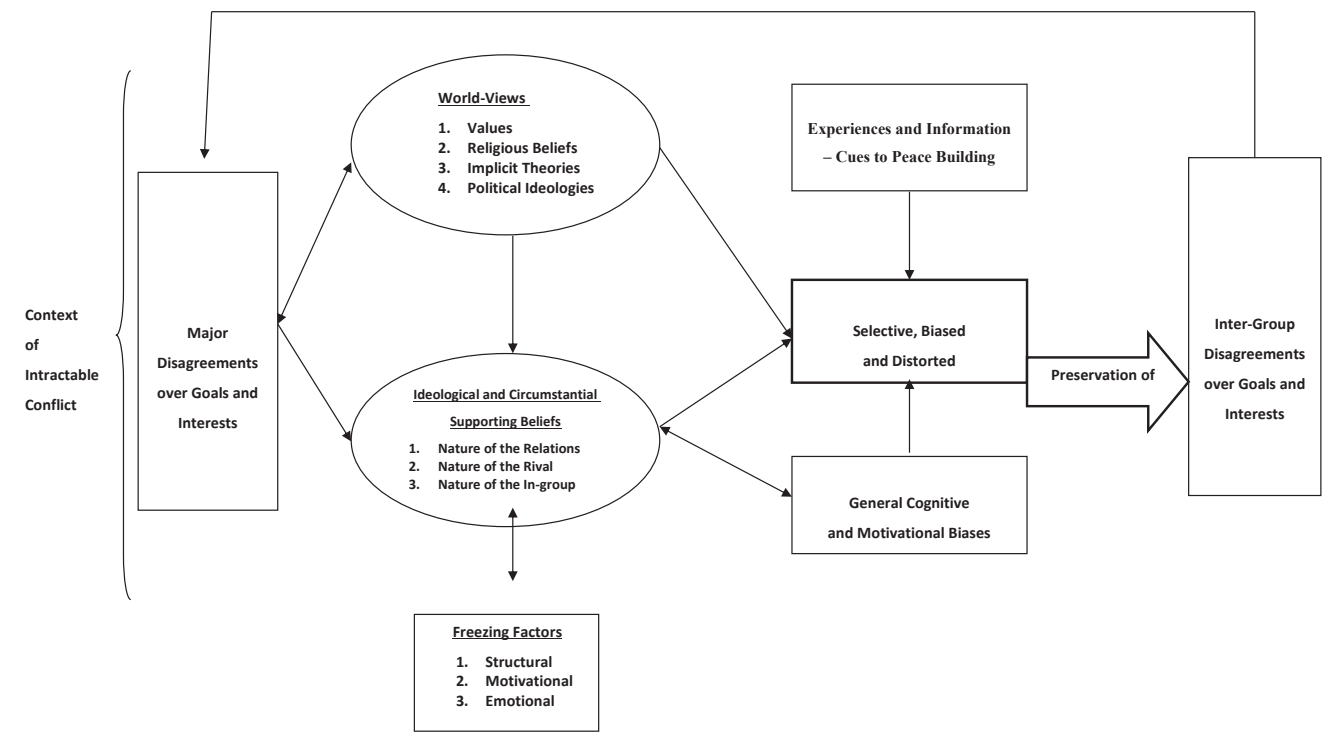

The reason for this closure before alternative information is freezing of the societal beliefs of the narrative, which is the essence of barriers' functioning (Kruglanski, 2004; Kruglanski \& Webster, 1996). The state of freezing is reflected in continuous reliance on the held societal beliefs that support the conflict, the reluctance to search for alternative information and resistance to persuasive arguments that contradict held positions (Kruglanski, 2004; Kruglanski \& Webster, 1996; Kunda, 1990). Freezing of the narratives of culture of conflict

\footnotetext{
${ }^{6}$ Still the process of change may take place with great difficulty, duration and obstacles.
} 
is based on the operation of cognitive, motivational and emotional processes, and a number of socio-psychological factors that will be now noted (see also the integrative model of socio-psychological barriers to peace making in Bar-Tal \& Halperin, 2011 for elaboration).

Freezing, as a cognitive process is fed by the rigid structure of the societal conflict supporting beliefs as they are held by many of the society members. Rigidity implies that these societal beliefs are resistant to change, being organized in a coherent manner with little complexity and great differentiation from alternative beliefs (Tetlock, 1989; Rokeach, 1960). It is important to note in the discussion of the cognitive factor that closure is also affected by general worldviews that are systems of beliefs not related to the particular conflict, but provide orientations that contribute to the continuation of the conflicts because of the perspectives, norms and values that they propagate (Bar-Tal \& Halperin, 2011).

Second factor leading to freezing is motivational because the held societal beliefs are assumed to be underlined by specific closure needs (see Kruglanski, 1989, 2004). That is society members are motivated to view the held beliefs of ethos of conflict and collective memory as being truthful and valid because they fulfil for them various needs (see for example, Burton, 1990).

The third factor that affects the freezing are enduring negative intergroup emotions such as fear. They function to close the psychological repertoire of society members and strengthen the rigidity of the societal beliefs. The link that connects between them and the societal beliefs is the appraisal component of the emotions. Each and every emotion is related to unique configuration of comprehensive (conscious or unconscious) evaluations of the emotional stimulus (Roseman, 1984) and this means that emotions are interpreted in view of the societal beliefs and they also instigate them once they are evoked (Halperin, Sharvit \& Gross, 2011).

In sum, freezing that is triggered by numerous reasons is the dominant cause for the functioning of the societal beliefs of culture of conflict as sociopsychological barriers. The barriers lead to selective collection of information, which means that society members involved in intractable conflict tend to search and absorb information that validates the societal beliefs of the repertoire while ignoring and omitting contradictory information (Halperin \& Bar-Tal, 2011; Kelman, 2007; Kruglanski, 2004; Kruglanski \& Webster, 1996; Kunda, 1990; Porat, Halperin, \& Bar-Tal, 2015). However, even when ambiguous or contradictory information is absorbed, it is encoded and cognitively processed in accordance with the held repertoire through bias, addition and distortion. 
The Middle East conflict and other intractable conflicts show us that the barriers are extremely powerful forces that prevent peaceful resolution of conflicts. This analysis does not include the economic-military-political interests that play a role in the will to continue the conflict. It focuses only on the ideological investments. People from an early age have been inculcated with well established, coherent, systematic and inter-related ideas about why to adhere to far-fetched national goals and how to disregard the goals of the other party; why to distrust, dehumanize and hate the rival; why to view one's own group in glorified terms as the eternal and sole victim of the conflict; how to disregard, deny and repress the suffering of the other group while focusing only on one's own suffering and omitting from the repertoire empathetic and moral considerations that may spoil this biased view of the conflict. This ideology is supported throughout life by various channels of communication and societal institutions that also cause all educational efforts in this vein to be perceived as reliable and trustworthy. They teach that all those who provide alternative views, from either inside or from outside, have negative intentions, are not reliable, and harm the causes of the group.

It is thus not surprising that so many bloody and protracted conflicts are still raging on this globe.

\section{Conclusions}

Real disagreements over tangible and non-tangible commodities influence people to launch harsh and violent conflicts that engage society members and lead to continuous suffering and hardship, as well as to considerable losses in human lives. Conflicts plague the involved societies and the international community with serious problems and challenges. Resolving these conflicts does not only require addressing the issues that stand at the centre of the disagreements, but also necessitate overcoming socio-psychological barriers that underlie these disagreements. Moreover, these barriers in protracted conflicts often become the major obstacles in resolving these intractable conflicts. They close the society members and prevent information processing that can provide alternative knowledge that can potentially advance peace-making. Such information is crucial for embarking on the road of peace as it may unfreeze the conflict-supporting societal beliefs.

We can learn from these observations that any analysis of intractable conflicts requires the use of a socio-psychological perspective, in addition to the use of other perspectives. Human beings perceive, evaluate, infer and act 
- they are active participants in events going on around them. These human psychological processes are integral parts of conflict interactions, as human beings are the only real actors on the conflict stage. Human beings make the decisions regarding the dissemination of information about the necessity of conflicts, the mobilization of society members to participate in them, the socialization of their children to continue the conflicts and carry them violently or reject their peaceful resolution. In essence, humans are the decision makers and therefore the psychological aspects embedded in human characteristics must be addressed in order to change human behaviour. Later, if they begin to view the situation of conflict differently, individuals may decide to disseminate the idea about the necessity of peace-making and mobilize society members for this goal. Hopefully, addressing the socio-psychological repertoire will create various socialization and mobilization mechanisms for peace-making and peace building. It is thus of crucial importance to advance knowledge that will shed light on the conditions, the contents, and the processes that convince societies members not only to embark on the peace building process in times of conflicts, but also that socialize them to prevent vicious and destructive conflicts and hatecycles with heavy costs to begin with.

We want to end the paper with two quotations by two political leaders that had the courage to break the walls of the barriers and both paid the ultimate price for these acts.

The president of Egypt Anwar Sadat, when arriving to make peace with Israel on November 20, 1977 in his speech in the Israeli Knesset said:

"As we really and truly seek peace, we really and truly welcome you to live among us in peace and security.

There was a huge wall between us which you tried to build up over a quarter of a century, but it was destroyed in 1973.... Yet, there remained another wall. This wall constitutes a psychological barrier between us. A barrier of suspicion. A barrier of rejection. A barrier of fear of deception. A barrier of hallucinations around any action, deed or decision. A barrier of cautious and erroneous interpretations of all and every event or statement. It is this psychological barrier which I described in official statements as representing 70 percent of the whole problem".

Seventeen years later Prime Minister of Israel Yitzhak Rabin, who was the architect of the Oslo process, when he received the Nobel Peace Prize in Oslo for this achievement on December 10, 1994 said: 
"We will pursue the course of peace with determination and fortitude. We will not let up.

We will not give in.

Peace will triumph over all our enemies because the alternative is grim for us all.

And we will prevail.

We will prevail because we regard the building of peace as a great blessing for us, and for our children after us."

These messages should be well learned and then practiced by those who strive to overcome the socio-psychological barriers to peace-making. 


\section{References}

Arrow, K. J., Mnookin, R.H., Ross, L., Tversky, A., \& Wilson, R. (1995). Barriers to conflict resolution. New York: W. W. Norton.

Avni, L., \& Klustein, E. (2009). Trojan horse: The impact of European government funding for Israeli NGOs. Jerusalem: NGO Monitor.

Bar-Tal, D. (1998). Societal beliefs in times of intractable conflict: The Israeli case. International Journal of Conflict Management, 9, 22-50.

Bar-Tal, D. (2000). Shared beliefs in a society: Social psychological analysis. Thousand Oaks, CA: Sage.

Bar-Tal, D. (2001).Why does fear override hope in societies engulfed by intractable conflict, as it does in the Israeli society? Political Psychology, 22, 601-627.

Bar-Tal, D. (2007). Sociopsychological foundations of intractable conflicts. American Behavioral Scientist, 50, 1430-1453.

Bar-Tal, D. (2010). Culture of conflict: Evolvement, institutionalization, and consequences. In R. Schwarzer \& P. A. Frensch (Eds.), Personality, human development, and culture: International perspectives on psychological science (Vol. 2, pp. 183-198). New York: Psychology Press.

Bar-Tal, D. (2013). Intractable conflicts: Socio-psychological foundations and dynamics. Cambridge: Cambridge University Press.

Bar-Tal, D., \& Halperin, E. (2011). Socio-psychological barriers to conflict resolution. In D. Bar-Tal (Ed.), Intergroup conflicts and their resolution: Social psychological perspective (pp.217-240). New York: Psychology Press.

Bar-Tal, D., Oren, N., \& Nets-Zehngut, R. (2014). Sociopsychological analysis of conflictsupporting narratives: A general framework. Journal of Peace Research, 51, 662 675

Berger, S. (2005). A return to the national paradigm? National history writing in Germany, Italy, France, and Britain from 1945 to the present. The Journal of Modern History, 77, 629-678.

Brown, R., \& Davis-Brown, B. (1998) The making of memory: The politics of archives, libraries and museums in the construction of national consciousness. History of the Human Sciences, 11, 17-32.

Burton, J. W. (Ed.) (1990). Conflict: Human needs theory. New York: St. Martin's Press.

Cairns, E. (1996). Children in political violence. Oxford, UK: Blackwell.

Carruthers, S. (2000). The Media at war: Communication and conflict in the twentieth century. New York: Palgrave.

de Jong, J. T. V. M. (Ed.) (2002). Trauma, war, and violence: Public mental health in sociocultural context. New York: Kluwer Academic Publishers Dixon. 
Devine-Wright, P. (2003). A theoretical overview of memory and conflict. In E. Cairns \& M.D. Roe (Eds.), The role of memory in ethnic conflict (pp. 9-33). Houndmills: Palgrave Macmillan

Dixon, J. M. (2010). Defending the nation? Maintaining Turkey's narrative of the Armenian genocide. South European Society and Politics, 15, 467-485.

Halperin, E., \& Bar-Tal, D. (2011). Socio-psychological barriers to peace making: An empirical examination within the Israeli Jewish society. Journal of Peace Research, 48, 637-657.

Halperin, E., Sharvit, K., \& Gross, J. J. (2011). Emotions and emotion regulation in conflicts. In D. Bar-Tal (Ed), Intergroup conflicts and their resolution: A social psychological perspective (pp. 83-103). New York: Psychology Press.

Horowitz, D. L. (2000). Ethnic groups in conflict. Berkeley: University of California Press. Kelman, H. C. (2007). Social-psychological dimensions of international conflict. In I. W. Zartman (Ed.), Peace-making in international conflict: Methods and techniques (Revised edition, pp. 61-107). Washington, DC: United States Institute of Peace Press.

Kriesberg, L. (1993). Intractable conflict. Peace Review, 5, 417-421.

Kriesberg, L. (2007). Constructive conflicts: From escalation to resolution (3rd edition). Lanham, MD: Rowman \& Littlefield.

Kruglanski, A.W. (1989). Lay epistemics and human knowledge: Cognitive and motivational bases. New York: Plenum.

Kruglanski, A. W. (2004). The psychology of closed mindedness. New York: Psychology Press.

Kruglanski, A. W., \& Webster, D. M. (1996). Motivated closing of the mind: 'Seizing' and 'freezing'. Psychological Review, 103, 263-283.

Kunda, Z. (1990). The case for motivated reasoning. Psychological Bulletin, 108, 480-498.

Milgram, N. A. (Ed.) (1986). Stress and coping in time of war: Generalizations from the Israeli experience. New York: Brunner/Mazel.

Papadakis, Y., Peristianis, N., \& Welz, G. (Eds.), (2006). Divided Cyprus: Modernity, history, and an island in conflict. Bloomington: Indiana University Press.

Peleg, I. (Ed.) (1993). Patterns of censorship around the world. Boulder, CO: Westview Press.

Porat, R., Halperin, E., \& Bar-Tal, D. (2015). The effect of socio-psychological barriers on the processing of new information about peace opportunities. Journal of Conflict Resolution, 59, 93-119

Robben, A., \& Suarez O. M. M. (Eds.) (2000). Cultures under siege: Collective violence and trauma. New York: Cambridge University Press.

Rokeach, M. (1960). The open and closed mind. New York: Basic Books.

Roseman, I. J. (1984). Cognitive determinants of emotions: A structural theory. In P. 
Shaver (Ed.), Review of personality and social psychology, vol. 5 (pp. 11-36). Beverly Hills, CA: Sage Publications.

Ross, L., \& Ward, A. (1995). Psychological barriers to dispute resolution. In M. Zanna (Ed.), Advances in experimental social psychology (Vol. 27, pp. 255-304). San Diego: Academic Press.

Tetlock, P. E. (1989). Structure and function in political belief system. In A. R. Pratkanis, S. J. Breckler, \& A. G. Greenwald (Eds.), Attitude structure and function (pp. 126151). Hillsdale, NI: Erlbaum.

Tint, B. (2010). History, memory, and intractable conflict. Conflict Resolution Quarterly, 27, 239-256. 


\title{
СОЦИО-ПСИХОЛОШКИ БАРИЕРИ ЗА МИРОљУБИВО РАЗРЕШУВАЊЕ НА ДОЛГОТРАЈНИТЕ КОНФЛИКТИ
}

\author{
Даниел Бар-Тал
}

\section{Кратка содржина}

Интензивните и насилни меѓугрупни конфликти кои беснеат во различни делови на светот се реални. Овие конфликти се концентрирани на несогласувањата што се фокусираат на контрадикторните цели и интереси во различни сфери и тие мора да бидат земени предвид при процесот на решавање на конфликтите. Познато е дека конфликтите потенцијално би можеле да се решат доколку не постојат моќните социо-психолошки бариери кои нив ги поттикнуваат и одржуваат. Овие бариери го инхибираат и го спречуваат напредокот кон мирољубиво решавање на конфликтот. Тие претставуваат главни пречки за започнување на преговорите, за нивно продолжување и за доаѓање до договор, а подоцна како такви се вклучуваат и во процесот на помирување. Овие бариери се наоѓаат и меѓу лидерите и кај останатите членови на заедницата инволвирани во насилните и долготрајни меѓугрупни конфликти. Тие почиваат на интегриран ефект на когнитивни, емоционални и мотивациски процеси, комбинирани со претходно постоечки репертоар на цврсти верувања кои ги поддржуваат, како и на светогледи и емоции кои овозможуваат селективна, пристрасна и искривено процесирање на информации. Ова процесирање го спречува продорот на нови информации што можат потенцијално да придонесат за олеснување на напредокот во мировниот процес.

Клучни зборови: йсихолошки бариери, ейос на конфлкикӣи, меѓуїруйни емоции,

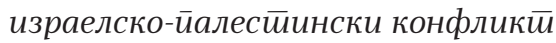


